\title{
SOSIALISASI PERILAKU HIDUP BERSIH DAN SEHAT (PHBS)
}

\author{
Adi Santoso \\ Progam Studi Ilmu Administrasi Negara \\ Sekolah Tinggi Ilmu Administrasi Pembangunan Jember \\ *Email: adisantoso@gmail.com
}

\begin{abstract}
ABSTRAK
Perilaku hidup bersih dan sehat adalah kesadaran, kemauan, dan kemampuan masyarakat mempraktekkan PHBS dengan tujuan derajat kesehatannya meningkat, tidak mudah sakit, meningkatnya produktivitas kerja setiap anggota keluarga yang tinggal dalam lingkungan sehat dalam rangka mencegah dan menanggulangi timbulnya penyakit dan masalahmasalah kesehatan, memanfaatkan pelayanan kesehatan, mengembangkan, dan menyelenggarakan upaya kesehatan bersumber masyarakat. Tempat pembuangan sampah juga perlu diperhatikan. Peran masyarakat sangat penting dengan meningkatkan pengetahuan, keterampilan,dan kesadaran masyarakat untuk berbuat sesuatu demi menjaga dan melindungi sumber daya alam. Pengelolaan dan pelesatarian lingkungan hidup adalah upaya untuk melestarikan dan memelihara fungsi lingkungan hidup untuk kelangsungan daya dukung dan daya tampung lingkungan hidup meliputi kebijaksanaan penataan, pemanfaatan, pengembangan, pemeliharaan, pemulihan, pengawasan, dan pengendalian lingkungan hidup. Salah satu upaya untuk meningkatkan peran masyarakat lokal dalam pengelolaan sumber daya alam dan wilayah pesisir dan laut adalah dengan meningkatkan pengetahuan, keterampilan dan kesadaran masyarakat untuk berbuat sesuatu demi melindungi sumberdaya alam. Pengetahuan dan keterampilan tersebut tidak harus berkaitan langsung dengan upaya-upaya penanggulangan masalah kerusakan sumber daya alam tetapi juga hal-hal yang berkaitan dengan usaha ekonomi, terutama dalam rangka membekali masyarakat dengan usaha ekonomi alternatif sehingga tidak merusak lingkungan
\end{abstract}

Kata kunci : Kebersihan, Lingkungan, Masyarakat 


\section{A. ANALISIS SITUASI}

Sampah merupakan sisa hasil penggunaan sumber daya oleh manusia. Hampir setiap hal yang dilakukan oleh manusia setiap harinya menghasilkan residu yang kita sebut sampah. Dari satu kegiatan utama seperti makan misalnya, berton-ton sampah telah dihasilkan; mulai dari sampah organik hingga non-organik, dari yang mudah dihancurkan tanah sampai yang membutuhkan waktu teramat panjang. Seiring dengan meningkatnya gaya hidup masyarakat modern serta kemajuan teknologi, mau tak mau jumlah sampah semakin bertambah. Di beberapa daerah perkotaan Indonesia contohnya, sampah tersebar dimana-mana; tidak peduli area publik maupun di depan rumah seseorang.

Masalah yang sering muncul dalam penanganan sampah desa adalah masalah biaya operasional yang tinggi dan sulitnya ruang yang pantas untuk pembuangan. Sebagai akibat biaya operasional yang tinggi, kebanyakan desa-
Desa di Indonesia hanya mampu mengumpulkan dan membuang sekitar $60 \%$ dari seluruh produksi sampahnya. Dari 60\% ini, sebagian besar ditangani dan dibuang dengan cara yang tidak saniter, boros dan mencemar.

Masalah sampah menjadi salah satu masalah kesehatan yang ditemui di Desa Sumberjambe. Teridentifikasi bahwa 95\% pengelolaan sampah masih belum memenuhi kesehatan. Diantaranya masyarakat yang membuang sampah dengan cara ditimbun, dibakar, bahkan membuang disembarang tempat termasuk dibuang ke sungai atau di pinggir jalan.

Berdasarkan uraian diatas maka diperlukan adanya perhatian dan pemahaman yang berkelanjutan tentang kebersihan dan kesehatan lingkungan

melalui kegiatan pendidikan kesehatan tentang pengelolaan sampah. Pengelolaan

sampah yang memenuhi syarat kesehatan sehingga menjadi salah satu kegiatan di 
masyarakat dalam upaya pencegahan dari berbagai penyakit akibat tidak berperilaku hidup bersih dan sehat.

2. Pengertian Kebersihan

\section{Lingkungan}

Undang-undang No. 23 tahun 1992 pasal 22 menyatakan bahwa kesehatanlingkungan

diselenggarakan untuk mewujudkan kualitas lingkungan yang sehat yaitu keadaan lingkungan yang bebas dari resiko yang membahayakan kesehatan dan keselamatan manusia (Marsaulina, 2004 : 2). Kebersihan adalah salah satu tanda dari keadaan hygene yang baik. Kebersihan badan meliputi kebersihan diri sendiri seperti mandi, gosok gigi, mencuci tangan, dan memakai pakaian yang bersih. Kebersihan lingkungan adalah kebersihan tempat tinggal, tempat bekerja, dan tempat awam. Kebersihan tempat tinggal dilakukan dengan cara mengelap tingkap dan perabot rumah, menyapu dan mengepel lantai, mencuci peralatan masak dan peralatan makan, membersihkan bilik mandi dan jamban, dan membuang sampah. Kebersihan lingkungan dimulakan dengan menjaga kebersihan halaman dan membersihkan jalan di depan rumah daripada sampah (Sangian, $2011: 3-4)$.

Manfaat menjaga kebersihan lingkungan antara lain (Laila, 2012 : 1):

1. Terhindar dari penyakit yang disebabkan lingkungan yang tidak sehat.

2. Lingkungan menjadi lebih sejuk.

3. Bebas dari polusi udara.

4. Air menjadi lebih bersih dan aman untuk di minum.

5. Lebih tenang dalam menjalankan aktivitas sehari-hari.

Kesimpulan dari pembahasan di atas yaitu pemahaman kebersihan lingkungan adalah kemampuan seseorang untuk mengerti atau memahami untuk menciptakan lingkungan yang sehat, aman, bersih, dan sejuk sehingga tidak mudah terserang berbagai penyakit.

B. Tinjauan tentang Perilaku Hidup Bersih dan Sehat (PHBS)

1. Pengertian Hidup Bersih dan Sehat (PHBS)

Perilaku hidup bersih dan sehat adalah upaya untuk memberikan 
pengalaman belajar atau menciptakan suatu kondisi bagi perorangan, keluarga, kelompok, dan masyarakat. Ini dilakukan dengan membuka jalur komunikasi, memberikan informasi, dan melakukan edukasi untuk meningkatkan pengetahuan, sikap, dan perilaku guna membantu masyarakat mengenali dan mengatasi masalahnya sendiri sehingga masyarakat sadar, mau, dan mampu mempraktekkan PHBS melalui pendekatan pimpinan(Advokasi), bina suasana (Sosial Suport) dan pemberdayaan masyarakat (Empowerment). Terdapat 5 tatanan PHBS yaitu PHBS Rumah Tangga,PHBS Sekolah, PHBS Tempat Kerja, PHBS Sarana Kesehatan, PHBS Tempat-tempat Umum.

2. Manfaat Perilaku Sehat dan Bersih

a. Rumah tangga:

i. Setiap rumah tangga meningkatkan kesehatannya dan tidak mudah sakit ii. Anak tumbuh sehat dan cerdas.

iii. Produktivitas kerja anggota keluarga meningkat dengan meningkatnya kesehatan anggota rumah tangga maka biaya yang dialokasikan untuk kesehatan dapat dialihkan untuk biaya investasi seperti biaya pendidikan, pemenuhan gizi keluarga dan modal usaha untuk peningkatan pendapatan keluarga.

b. Masyarakat:

i. Masyarakat mampu mengupayakan lingkungan yang sehat.

ii. Masyarakat mampu mencegah dan menanggulangi masalah-masalah kesehatan.

iii. Masyarakat memanfaatkan pelayanan kesehatan yang ada.

iv. Masyarakat mampu mengembangkan Upaya Kesehatan Bersumber Masyarakat (UKBM) seperti posyandu, jaminan pemeliharaan kesehatan, tabungan bersalin (tabulin), arisan jamban, kelompok pemakai air, ambulans desa, dan lain-lain.

\section{URGENSI PROGRAM}

Sampah dan pengelolaannya kini menjadi masalah yang kian mendesak di kota maupun di desa di Indonesia, sebab apabila tidak dilakukan penanganan yang baik akan mengakibatkan terjadinya perubahan keseimbangan 
lingkungan yang merugikan atau tidak diharapkan sehingga dapat mencemari lingkungan, baik terhadap tanah, air dan udara. Oleh karena itu untuk mengatasi masalah pencemaran tersebut diperlukan penanganan dan pengendalian terhadap sampah. Penanganan dan pengendalian akan menjadi semakin kompleks dan rumit dengan semakin kompleksnya jenis maupun kompisisi dari sampah sejalan dengan majunya kebudayaan.

\section{TUJUAN DAN MANFAAT}

\section{PROGRAM}

Program "Perilaku Hidup

Bersih dan Sehat (PHBS)" memiliki tujuan yaitu sebagai berikut:

i. Menambah pengetahuan pada masyarakat tentang Perilaku Hidup Bersih

Dan Sehat (PHBS);

ii. Membiasakan masyarakat membuang sampah yang benar;

iii. Menciptakan lingkungan yang indah, bersih, dan sehat;

\section{E. DESKRIPSI PROGRAM}

E1. Bentuk Kegiatan
Program penyuluhan kesehatan tentang pengelolaan sampah memiliki dua kegiatan yaitu sebagai berikut:

1) Sosialisasi di tiga desa di Kecamatan Jenggawah, yaitu Desa Jatisari, Sruni dan Jatimulyo yang akan dilaksanakan pada 16 Mei 2019 Sosialisasi di Desa Jatisari dan Desa Sruni dilakukan dengan metode pemaparan dan diskusi kepada kader PKK dan Posyandu desa. Untuk sosialiasi di Desa Jatimulyo dilaksanakan dengan penyebaran pamlet kepada kelompok-kelompok masyarakat di desa.

2) Penyelenggaraan Program Penyuluhan kesehatan tentang pengelolaan sampah dilakukan terpusat di Desa Sruni pada Senin 16 Mei 2019. Penyelenggaraan penyuluhan secara terpusat di Desa Sruni dilakukan dengan adanya aktivitas masyarakat yaitu "Program On The Spot" dari tim pelaksana. 


\section{E2. Target Group}

Program

penyuluhan

kesehatan tentang pengelolaan sampah ini merupakan program penyuluhan yang dilaksanakan dengan melibatkan kelompokkelompok masyarakat yang ada di desa seperti Kader PKK, Kader Posyandu, Kelompok Pemuda dan Kelompok Keagamaan.

\section{E3.Target Pencapaian}

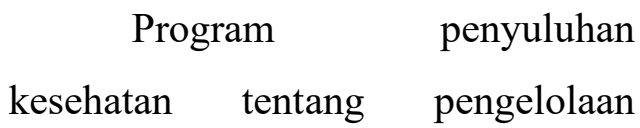
sampah memiliki target pencapaian salah satunya:

1) Target pencapaian sosialisasi, adalah meningkatnya pemahaman dan ketertarikan masyarakat yang sadar tentang Perilaku Hidup Bersih dan Sehat (PHBS) dengan membiasakan diri membuang sampah yang benar

2) Target pencapaian penyuluhan adalah 45 pendaftar yang diasumsikan dari 3 desa terdapat masingmasing 15 pendaftar.

\section{F. PELAKSANAAN PROGRAM}

\section{F1. Pelaksanaan Sosialisasi}

Pelaksanaan sosialisasi dilaksanakan untuk meningkatkan pemahaman, kesadaran dan ketertarikan masyarakat tehadap pengelolaan sampah. Artinya, sosialisasi ini menjadi faktor pendukung utama untuk kesuksesan penyelenggaraan Perilaku Hidup Bersih dan Sehat (PHBS). Sosialisasi dilakukan dengan dua model yaitu temu warga dan model penyebaran pamflet.

\section{F2. Pelaksanaan Program}

$$
\text { Program Penyuluhan }
$$

kesehatan tentang pengelolaan sampah dilaksanakan pada Senin, 16 Mei 2019 pukul 09.00-12.00 bertempat di balai desa Jatisari Kecamatan Jenggawah. Pendaftar sosialisasi tercatat sebanyak 46 orang. Dari 46 Orang tersebut, ternyata tidak semuanya hadir untuk sosialisasi, karena beberapa alasan, yaitu sebagai berikut:

1. Beberapa peserta tidak bisa hadir dikarenakan sibuk bekerja. 
2. Beberapa peserta tidak hadir tanpa alasan.

Pada pelaksanaan program berlangsung, peseta sosialisasi yang hadir akan diberikan materi terkait sosialisasi pengelolaan sampah. Agar masyarakat memahami dan bisa membiasakan diri membuang sampah yang benar. Setelah peserta mengikuti sosialisasi, panitia akan memberikan demonstrasi tentang pengelolaan sampah yang benar.

Dari pencapaian pelaksanaan program tersebut, diharapkan masyarakat memahami arti penting pengelolaan sampah bagi diri sendiri maupun masyarakat luas. Diharapkan untuk kedepannya setelah pelaksanaan sosialisasi ini, masyarakat sadar tentang Perilaku Hidup Bersih dan Sehat (PHBS) dengan membiasakan diri membuang sampah yang benar sehingga terciptakan lingkungan yang indah, bersih, dan sehat

\section{G. PENUTUP}

Demikian laporan pengabdian kepada masyarakat dengan tema "Sosialisasi Perilaku Hidup Bersih dan Sehat (PHBS)" ini disampaikan. Atas perhatian dan kerjasamanya disampaikan terima kasih.

\section{DAFTAR PUSTAKA}

Ambarwati, 2008. Hubungan Antara Tingkat Pengetahuan Ibu Rumah Tangga Dengan Perilaku Hidup Bersih dan Sehat Pada Tatanan Rumah Tangga di Wilayah Kerja Puskesmas purwantoro II Kabupaten Wonogiri. Skripsi. Surakarta : IKP

Arikunto, S. 2006. Prosedur Penelitian Suatu Pendekatan Praktik Edisi Revisi VI. Jakarta : PT. Rineka Cipta.

Azwar, 2005. Sikap Manusia Teori dan Pengaruhnya. Edisi 2, Yogyakarta: Pustaka Pelajaran

Budiarto, E. 2003. Metode Penelitian Kedokteran Sebuah Pengantar. Jakarta : EGC

Depkes RI. 2007. Krida Bina Perilaku Hidup Bersih dan Sehat. Jakarta. 
Departemen Kesehatan RI. 2005. Perilaku Hidup Bersih dan Sehat di Indonesia. Jakarta.

Dinkes Jawa Tengah. 2010. Pedoman Perilaku Hidup Bersih dan Sehat (PHBS) di Institusi.Semarang.

Dinkes Sulsel, 2010. Kebijakan Indonesia sehat 2010. Available on: http://2010/10/pelaksanaanphbs-di-sekolah.html. Tanggal Update : 4-1-11

Dinkes Prov Jateng. 2014. Profil Kesehatan Jawa Tengah. http://www.dinkesjatengprov.go. id/dokumen/2013/. Diakses pada tanggal 14 Juni 2016.

Dirgahayu, 2015. Hubungan antara Tingkat Pengetahuan dengan Perilaku Hidup Bersih dan Sehat Siswa di Madrasah Ibtidaiyah Muhammadiyah Gonilan. Kartasura

DKK Boyolali, 2010. Indikator dan Definisi Operasional PHBS Institusi Pendidikan Provinsi Jawa Tengah.
Farida, 2013. PHBS (Perilaku Hidup Bersih dan Sehat) di Sekolah Kelurahan Namogajah Kecamatan Medan Tuntungan . Skripsi. Sumatera. 